\title{
Journal of International Affairs
}

Vol. 3, 68-83, 2020

Doi: https://doi.org/10.3126/joia.v3i1.29084

Department of International Relations and Diplomacy

Tribhuvan University, Kathmandu, Nepal

\section{Critical Issues Related to Connectivity in South Asia}

Hari P. Chand

\begin{abstract}
This paper mainly deals with connectivity of Nepal with neighboring countries and beyond. Nepal entered into an agreement with India for a Raxaul - Kathmandu railway line survey last year. After rail connectivity is established with India, Nepal is expected to benefit through transport costs compared to existing road connectivity. Nepal also signed an MoU with India for the development of inland water ways during the last visit by Prime Minister KP Sharma Oli to India. This is expected to provide Nepal with greater opportunities of better connection with Indian ports to promote trade with her southern neighbor and beyond. Moreover, Nepal and Chinese governments have agreed to work together to construct a rail link between Kerung and Kathmandu. This should allow Indian and Chinese railways to link in Kathmandu although that may yet take some time. Similarly, if Nepal deals tactfully with India and Bangladesh to make the Kathmandu-Kakarvitta-Phulbari-Banglabandha corridor function smoothly, there is a high possibility of establishing China-Nepal-India-Bangladesh (CNIB) Economic Corridor in the future. This paper attempts to explain the critical geo-political issues and challenges in connectivity facing Nepal. This paper is based on secondary data and both the qualitative and quantitative methods have been adopted for analysis. The key point of arguments presented by the paper is that all South Asian countries need to come up with "Connectivity Diplomacy", preferably on the Track 1.5 level.
\end{abstract}

Keywords: Nepal-India Connectivity, BIN Plus One, Regional Connectivity 


\section{Introduction}

Direct connection between and among countries in the same region accelerates trade intensity among them. Transport connectivity for landlocked countries categorised broadly into three types: 1) Road Link, 2) Rail Link and 3) Air Link. Sea route can be another category for island countries like Sri Lanka and others with direct access to the sea. Connectivity is based on the level of infrastructural development. Construction of road, cross-border railway and international airports is the infrastructural pre-requisite for international connectivity. In the context of regional cooperation, all forms of connectivity among all South Asian countries are vitally important.

Connectivity is also psychological and must transcend the mental borders that people tend to have. The hearts and minds of people must be connected first. Only then can the goal of physical connectivity be achieved. With the removal mental borders, people-to-people bonds are enhanced. This results in the meaningful cooperation in all areas in the region. Constructivist soft power is required to build connectivity of the hearts. The languages, religions and cultures of the countries are similar. Their norms and values are oriental discourse. Any kind of connectivity and cooperation should ensure the national interests of all countries are not encroached upon. The norms and provisions of global and regional governance, international law and principles of Panchasheel must not be trespassed by any particular country.

Basically, a nation has two types of national interests: a) primary national interest and b) secondary national interest. Primary interests are: protection of the country's territory, sovereignty and independence. Secondary national interests can be understood as the interest of the people and their properties outside the territory of the country, on the one hand, and prosperity of the people and the nation as a whole (Ghosh, 2013: 66). Because of international law, principles of Panchsheel, UN charter and provisions of global and regional governance, primary national interests are not so much at risk compared to secondary national interest, especially in this era of globalization. The secondary interest of small economies like Nepal is, however, threatened by their more powerful counterparts. This is borne out by their economic data. In 2018, for example, Nepal's ratio of import to export was 19.23. In 2017, Nepali exports amounted to around 78 billion rupees while its imports stood at around 1.5 trillion rupees (Byanjankar, 2018: 6). Nepal has been facing the critical challenges brought on by a trade deficit that has shot up since being member of WTO. Regional connectivity in South Asia has to address the issues of trade of small economies. In other words, connectivity partners must remain sensitive to this secondary national interest and address it before its problems turn it into a primary national interest that could threaten the very possibility of cooperation in the first place. Trade, tourism and investment in Nepal are key areas to be focused on for defending Nepal's secondary national interest.

Nepal has a stable government with a two-thirds majority in parliament headed by Mr. Khadga Prasad Sharma Oli. After the elections, all the three tiers of the government- federal, provincial and local- are working to achieve this goal. The formation of a two-thirds majority government of a communist party in Nepal, through the democratic process, is a rare observation in world politics, ever since Communist Manifesto was drafted 171 years ago (Pradhan, 2018: 1).Almost 74 per cent of House of Representatives is in the support of Oli's government (House of Representatives website).Prime Minister Oli has said that the first year of the government has been able to lay a solid foundation for further promotion of the nation's secondary interest. His own allegory: "The first year has built such a strong foundation that not only a two or a four storied building, but a thousand storied one can be constructed on it (Onlinekhabar website)."The government goal in economic development is made crystal clear by the slogan 
"Prosperous Nepal, Happy Nepali". None of these promises can be said to have been properly fulfilled with an acceptable level of trade balance, investment promotion, tourism development and infrastructure development. Nepal's connectivity with South Asian countries would augur well for Nepal's government to realize its promises.

\section{Connectivity-The Game Changer}

Parag Khanna writes:

"The globalization debate is saturated, but it remains more pertinent than ever. At the root of this discussion lies the notion of connectivity-exemplified by the increasing volume and sheer scale of intra and inter-regional movement of people, goods, services, capital, and data. Today's reality is dominated by the opportunities and effects of connectivity - the megatrend of the 21st century (Khanna,2017: 21).

Parag Khanna's opinion is related to the notion of globalization and, by extension, economic liberalization. Today, the world is dominated by liberalization policy. The emergence of Bretton Woods System in 1944 basically opened avenues for liberalization policies throughout the world. However, they saw their full-fledged materialization only after the end of Cold War in a uni-polar world. The World Bank, one of the institutions of the Bretton Woods system, provides zero to low-interest credits and grants to developing countries for infrastructure development and other sectors (Website of World Bank).Similarly, Asian Development Bank (ADB) has prioritized infrastructure development in developing countries. The official website of ADB says that infrastructure - defined as a country's physical facilities, such as roads, power plants, and bridges - is critical for regional development. Poor infrastructure slows economic growth and limits the investment needed to create the jobs that help lift people out of poverty (Website of ADB).Likewise, Asian Infrastructure Investment Bank (AIIB) was established for infrastructural development in developing countries in the Asia Pacific region. AIIB claims, "By investing in sustainable infrastructure and other productive sectors in Asia and beyond, we will better connect people, services and markets that over time will impact the lives of billions and build a better future (Website of AIIB)." These global and regional institutions have been investing millions of dollars in infrastructure development which ultimately boosts regional connectivity. As Khanna has said, regional connectivity will, in turn, enhance and promote intra and inter-regional movement of people, goods, services, capital, and data.

It is assumed that connectivity changes the geopolitics of a country and a region. As Saul B. Cohen (2010) writes, as quoted by Semra Rana Gokmen, "Geopolitics is the analysis of the interaction between, on the one hand, geographical settings and perspectives and, on the other hand, political processes. (...) Both geographical settings and political processes are dynamic, and each influences and is influenced by the other. Geopolitics addresses the consequences of this interaction (Gokman, 2010: 16). Geographical setting is related to geography, whereas perspectives belong to political actors and ideologies. When a nation is connected with other countries by land, sea and air, the movement of new political actors also increases, which implies interaction between the geographical setting and existing actors in that country. Sometimes, the newly emerged actors can change the political game in a certain geography. It is believed that China-Pakistan Economic Corridor (CPEC) is changing the game not only around the Baluchistan region (Pillalamarri, 2016: 2) but also in Arabian Sea and beyond. He writes that the port access offered by Gwadar in Baluchistan is an important component in China's 
emerging transportation network across Asia (Ibid). Although western powers claim that that the Chinese presence in Baluchistan via CPEC is strategic, Chinese scholars deny that claim. Nonetheless, the main theme is that once the CPEC connectivity is complete, the strategic and economic game will not remain the same. In a similar vein, strong connectivity has to be built among the South Asian countries to change the state of poverty, underdevelopment and trade constraints not to mention the economic status of landlocked countries like Nepal, Afghanistan and Bhutan that lack access to the sea.

\section{Regional Connectivity in South Asia}

Five countries, out of the South Asian eight, are connected with the second largest economic power of the world China, which is also the largest country in terms of population. The world's second largest country in terms of population is in South Asia- India. Two of the ten nuclear powers of the world are South Asian countries- India and Pakistan. Two of the world's major civilizations- Chinese civilization and Indus Valley civilization-are in Asia. Nepal Valley Civilization is sandwiched between these two and finds itself overshadowed due to lack of vibrant research. It is Nepal that has been connecting these two great civilizations since time immemorial. The second and fifth largest economies, i.e. China and India respectively, are part of or connected with South Asian region. These are pointers to the central role of South Asian countries in global politics and economics, but without proper connectivity, all this will not mean much.

Connectivity in South Asia not only accelerates economic growth but also improves regional cooperation. There are eight objectives of South Asian Association for Regional Cooperation (SAARC) out of which two are related with economic growth and prosperity. They are: a) to accelerate economic growth, social progress and cultural development in the region and to provide all individuals the opportunity to live in dignity and to realize their full potentials; and b) to promote active collaboration and mutual assistance in the economic, social, cultural, technical and scientific fields (SAARC, 1985). These common objectives of SAARC can only be achieved when the region is connected by advanced infrastructure and technology. For this regional cooperation is important.

Shyam Saran (2018) writes in Hindustan Times, "Transport corridors are the arteries through which trade, commerce and people flow within and across countries. Now in our digital age, fibre optic submarine cables run thousands of kilometers under the sea connecting North America and Europe, Europe and Asia and continental Asia to archipelagic Asia (Saran, 2018)." His message is that the connectivity today should go digital and that South Asian regional connectivity should be digitalized.

Bangladesh believes that connectivity between Bangladesh and neighbouring countries including India have received a great boost during the last ten years from Bangladesh's proactive stance on enhancing connectivity in South and South East Asia. The leadership wants to make Bangladesh a connectivity hub. The logic is driven by Bangladesh's crucial role in the Bay of Bengal Initiative for Multi Sectoral Technical and Economic Cooperation (BIMSTEC).

Nepal for its part believes that it has now become a land-linked rather than landlocked country after signing the Belt and Road Initiative (BRI). Many Nepalese scholars have argued for Nepal 
seamlessly connecting China and South Asia. For this, advanced connectivity among China, Nepal and India is the best option. A writer argues, "Nepal cannot alter its geography or its history, but under BRI, Nepal definitely has a significant opportunity to benefit and affiliate with the economic potentials offered by China in the days ahead and appear as a golden bridge between China and South Asia."ADB has also published a report entitled "A ConnectivityDriven Development Strategy for Nepal: From a Landlocked to a Land-Linked State.'Like India, Bangladesh and Nepal, other South Asian countries have also been looking at connectivity from their own perspective.

BIMSTEC Transport Infrastructure and Logistics Study (BTILS) is now assisting the Study's updating, recommends strategies, policies, and programs for the development of transport and logistics systems for connectivity within and between South Asia and Southeast Asia.The report indicates the importance of intra and inter-regional connectivity between South Asian and Southeast Asian nations for mutual economic gains. Similarly, the 2010 SAARC summit held in Thimphu agreed to expedite negotiations to finalize transport facilitation agreements on motor vehicles and railways. Point Number 27 of the Thimphu declaration says, "The Leaders called for collaborative efforts to achieve greater intra-regional connectivity and endorsed the recommendation to declare 2010-2020 as the "Decade of Intra-regional Connectivity in SAARC". They agreed on the need to expedite negotiations with a view to finalizing the two agreements on Motor Vehicles and Railways (Indian Ministry of External Affairs website)." Five years after the Thimphu declaration, the BBIN [Bangladesh, Bhutan, India and Nepal] countries entered into a landmark Motor Vehicles Agreement (MVA) in 2015. A report published by ORF [Observer Research Foundation] says, "The coordinative architecture of the BBIN has given rise to the South Asian Growth Quadrangle, which facilitates, formulates, implements and reviews quadrilateral agreements for the benefit of the entire area. Such partnership will not only pave the way for a transport corridor but also facilitate the flow of trade." But, in early 2018, Bhutan withdrew from the motor vehicle agreement on BBIN signed in 2015. The Bhutanese fear is that the implementation of the deal may impact its own transporters and lead to degradation of environment due to vehicles entering from other countries outnumbering its own(Bose, 2018).But if the BBIN economic corridor gets implemented successfully, member countries will benefit through mutual economic cooperation despite having some suspicion from the strategic perspective.

Another major connectivity project in South Asia is Bangladesh-China-India-Myanmar Economic Corridor (BCIM-EC). It is also one of the six major BRI corridors .The BCIM Forum for Regional Cooperation project, which was initially known as the "Kunming Initiative," was founded in 1999 (Karim and Islam, 2018).Patricia Uberoi (2013) writes:

The thinking behind the Kunming Initiative is revealed in a remarkable note, titled 'Proposition on Formation of "Sub-regional Cooperation Zone of China, India, Myanmar and Bangladesh"', canvassed by Professor Che Zhimin (then Deputy Director of the Economic and Technological Research Centre of the Yunnan Provincial People's Government), during a visit to India in the previous year (2010) (Uberoi, 2013).

The purpose of BCIM-EC is to build a win-win situation in economic growth and cooperation for prosperity along the routes encompassing 165,000 square kilometers of land with a population of 440 million people. The route can generate huge economic benefits through multilateral trade, investment, movement of tourists and communication linkage. It aims for 
economic integration of the quadrant countries, which would enable the integration of Asia and others as well. The three T's agenda (Trade, Transport and Tourism) and TTE (Trade, Transport and Energy) is the major priority of the corridor. Secondly, the corridor wants to integrate the social, cultural and environmental milieus in the sub region. It is a 2,800-kilometer long proposed economic corridor that starts from Kolkata connecting with Dhaka and Sylhet through Benapole/Petrapole on the India-Bangladesh border before again entering India near Silchar in Assam. After entering through Imphal, the road will eventually reach Kunming via Ruili, Longling and Dali by moving through the Tamu Kalewa friendship road in Myanmar, and then crossing Mandalay and Lashio (Karim and Islam, 2018).

The next connectivity project that touches one of the South Asian countries is CPEC. The CPEC project is significant precisely because the port of Gwadar is one of the points where the Belt intersects. The corridor is based on a number of projects that will link China to central Asia and Europe in the longer run. CPEC may connect Xinjiang, the largest province of China, with Pakistan's Gwadar port (Rafiq, 2016). The port is a linchpin for China's BRI dream, providing its maritime silk route with a link to the Arabian Sea. Similarly, that port at the mouth of the Persian Gulf provides China with the shortest route to the oil rich Middle East, Africa and most of the western hemisphere. Gwadar will have an estimated capacity to handle 19 million tons of crude oil per year, which will be sent to China after being refined at the port (Shahid, (2016). The $2000 \mathrm{~km}$ long road and rail network in Pakistan costing 10.63 billion dollars to connect with Kasghar and a network of gas pipelines to connect Pakistan with Iran are also a part of the infrastructure to be built under China's OBOR initiative and related with the Gwadar port. The initial announcement of the 46 billion dollar CPEC was made in 2015, while the Chinese president, Xi Jinping, was in a visit in Pakistan. India has been opposing the planned CPEC basically for two reasons. First, the route passes through the disputed areas of Gilgit-Baltistan between India and China- and Kashmir- between India and Pakistan. Secondly, India suspects that the construction of the Gwadar port would make it possible for China to put up a naval base there to access Indian Ocean Region (IOR).

Similarly, there are two major connectivity routes proposed under BIMSTEC, which connect India with Myanmar and Thailand. The first is the Kaladan multimodal project to link India and Myanmar (Kolkata to Sittwe Port in Myanmar). The second is an Asian trilateral highway connecting India and Thailand through Myanmar. The $109 \mathrm{~km}$ long road project began construction in 2018 after a long delay. It will connect the Paletwa river turmoil to Zorinpui on the Mizoram border in Myanmar, as part of the 484 million dollar Kaladan Multimodal project (Bose, 2018). The Asian trilateral highway is an ambitious project, which Delhi hopes will be its gateway to ASEAN as India would then be the gateway to South Asia for ASEAN. The first $160 \mathrm{~km}$ stretch of the $1300 \mathrm{~km}$ long highway is called the India-Myanmar Friendship Highway (IMFH).

\section{Nepal in Connectivity}

In 1973, during King Birendra's China visit, talks were mostly focused on building QinghaiLhasa Railway, as it would ultimately connect China with Nepal (Sangroula, 2017: 9). After 43 years of those talks, Nepal has finally entered the railway project. It is expected that the country 
will now be connected by rail link with China after about a decade. One of the historic agreements made during Oli's second visit to China as Head of Government was the signing of an $\mathrm{MoU}$ on railway connectivity. Both countries underscored it as the most significant initiative in the history of bilateral cooperation and hoped that it would herald a new era of cross-border connectivity (Chand, 2018). Based on this understanding, a Chinese team of experts completed a preliminary study on railway construction to link Kathmandu with Kerung [called Geyrong in China] and submitted their report to the government of Nepal in Dec, 2018. Earlier, a Transit Trade agreement" (TTA) was inked during Prime Minister Oli's first official visit to China conducted from March 20 to 27, 2016. This theoretically opened the way for Nepal to access the sea via the Tianjin port of China which is almost 3500 kilometer away from Nepal. If the transit trade agreement is fully implemented, Nepal will not only be the gateway for China to South Asia but also China will be the next gateway for Nepal to North East Asian Nations.

Dev Raj Dahal opines that the old concept of Nepal acting as a buffer state for Asian powers was rejected when King Birendra, in the 1970s and 1980s, articulated that the nation was a gateway between South Asia and Central Asia (Adhikari, Chaulagain, Dhakal, and Subedi, 2013). That gateway concept is now coming to fruition through the transit trade agreement and MoU on BRI. Li Tao (2017) writes, "South Asia has an important geostrategic position in the development of $B \& R$ and is a gateway for China to promote the initiative westward (Tao, 2017).What this means is that Chinese scholars see Nepal as the gateway to South Asia and, further, South Asia as the gateway to the rest of the world.

China, in recent years, has come up proactively in pushing for the implementation of BRI with Nepal and partnering with South Asian countries. India did not participate in B\&R summit in May, 2017 in Beijing, however, China has expected that a train from Beijing to Bihar will be a reality in the next decade under the BRI.

The rail network of China, which was expected to be completed by 2020 up to Kerung near the border with Nepal, will create the environment for Nepal to act as a vibrant bridge between two Asian giants. The bridge discourse, regarding India and China, was reintroduced by Baburam Bhattarai in 2012 sees Nepal taking advantage from the rapid economic development of the two biggest and fast growing economies. But, now, the discourse is turning towards the Gateway concept. According to the Spotlight news magazine, for Bihar, trade with China through the rail link will be easier along this route than through Kolkata, saving time, cost and distance. The distance from Rasuwagadhi to Birgunj, which borders Bihar, is only $240 \mathrm{~km}$. In other words, import and export of goods and commodities between Bihar and China is viable through Nepal.

The argument is that the Indians have seemingly realized that the impenetrable Himalayan frontier has already been penetrated. Although trans-Himalayan roads were already there in the past, with the plan of China to rail link Kerung with the rest of China and, in the future, up to Kathmandu the "impenetrable frontier" thesis will have gone for good. Nihar Nayak (2014) writes, "The Himalayas as a natural frontier may have become less relevant in an era of nuclear weapons, globalization, technology and the improvement in the Sino-Indian relationship in recent years" (Nayak, 2014). As already mentioned, China has agreed to provide transit facility to Nepal from four Chinese sea ports, namely Tianjin, Shenzhen, Lianyungang and Zhanjiang, and three Chinese dry ports- Lanzhou, Lhasa and Shigatse (my Republica website).These 
developments prove that China will be connected soon with South Asia via Nepal through the road and rail networks. This will be a milestone for Nepal's connectivity with her neighbours.

Similar developments are taking place on the Indian side as well. On April 7, 2018, the two governments issued a joint statement on expanding rail linkages, agreeing to construct a new electrified rail line, with India's financial support, to connect the border town of Raxaul in India to Kathmandu (Ministry of External Affairs, 2018). In August 2018, there was an exchange of a Memorandum of Understanding between the Government of India and the Government of Nepal regarding preliminary engineering-cum-traffic survey of abroad gauge line between Raxaul and Kathmandu with the prime ministers of both countries as witness. If the MoU came into the force for constructing the rail link, another breakthrough will have happened in Nepal's neighborhood policy. Nepal will have to work hard to maximize the benefits with lower investment and risk. For that, Nepal's domestic policy should be focused on ways to do it. One popular recommendation is that Nepal must gear itself to produce more to take advantage of the new transport networks and the two greatest markets.

Likewise, on $7^{\text {th }}$ April, 2018, Nepal and India signed an MoU on inland waterways development. According to the MoU draft:

The Prime Ministers of India and Nepal recognized the untapped potential of inland waterways to contribute towards overall economic development of the region. Taking cognizance of their geographies and noting the development of inland waterways in both countries, the two Prime Ministers took the landmark decision to develop the inland waterways for the movement of cargo, within the framework of trade and transit arrangements, providing additional access to sea for Nepal. This new initiative would enable cost effective and efficient movement of cargo. The Prime Minister of Nepal noted the enormous impact the additional connectivity would have on the growth of business and economy of Nepal (Ministry of External Affairs, 2018).

In September 2018, A Nepali technical team visited Varanasi of India on its way to Kolkata for the purpose of a study of the infrastructural construction needed for inland waterways in India and explored ways to develop the waterways up to the Nepal border. There are various routes to extend the waterways to Nepal. India is launching inland waterways in Bihar and Uttar Pradesh soon and has expressed readiness to extend them up to the Nepal border via Narayani River. India has already begun building infrastructure to develop inland waterways from Kolkata to Varanasi via Ganga River. Once completed, Nepal-bound cargos from third countries can be transported from Kolkata to Varanasi that can then be brought in to Birgunj and Bhairahawa via rail and roads (Neupane, 2018).Regarding the best option for Nepal for export and import, the Indian officials have proposed that Nepal can export and import using big vessels from Kolkata to Kalughat in Bihar and then use smaller boats to transport them from and to Nepal. Nepal can alsousethe $180 \mathrm{~km}$ Kalught-Raxual road. Similarly, they have also proposed that Nepal can transport goods on big vessels through the Kolkata-Shaibgunj waterway and ferry them using smaller vessels up to the Nepal border. Or, Nepal can use the150km Shaibgunj-ManihariBirgunj road corridor for secondary transportation. India has also proposed the use of crossborder railway lines, which are under construction, at various border points. In this way, Nepal will benefit from inland waterways development with the cooperation of India, which will 
accelerate not only bilateral trade but also ease trade with third countries.

Various points in Nepal's southern and northern borders are open for movement of people and goods. Some of them are major ones taking most of the load of such movement. They are Kakarvita, Birgunj, Belhiya-Bhairahawa, Nepalgunj, Dhangadhi and Mahendra Nagar and lie along the southern border. Roads through these points are either being upgraded or a plan to do so is on the anvil. Other connectivity infrastructure including digitalization need to be expanded, renovated, upgraded and developed to handle the ever growing traffic. Along the northern border lie Olangchungola (Tiptala Pass), Kimathanka (Lengdup), Lamabagar (Lapchi), Tatopani (Sindhupalchok), Kerung -Rasuwagadhi, Gorkha Larke (Lajyang Pass), Mustang (Korala), Mugu (Nagcha) and Humla (Hilsa) (Shrestha, 2015). Among these mountain passes most of the trade takes place through Tatopani and Rasuwa in central Nepal. Dry ports are also being constructed there to meet the growing demand. The immediate need is to take the load off these two central passes along the northern belt and distribute it evenly to the east and the west of the country. This will enable people from other parts of Nepal to have direct trade and transit access to China, without making a detour through central Nepal to do so. It is in accordance with this need, other passes in the east and the west are also being upgraded, several of which have already received priority.

\section{CNIB Economic Corridor (BIN plus One)}

One of the geo-economically feasible corridors linked with Nepal is the proposed Nepal-China Economic Corridor. This is a bilateral project and has been debated for the last couple of years. After the Chinese rail links Kathmandu and Kerung and the Indian one links Kathmandu and Raxaul, this immediately opens the way for linking another South Asian country with the network. For this quadrilateral,i.e. China-Nepal-India-Bangladesh (CNIB), economic corridor, Bangladesh is the ideal candidate. The corridor can be termed as BIN plus one (KC and Chand, 2018). The CNIB economic corridor is actually a new debate in South Asian connectivity, which, if implemented, will benefit all the four countries in terms of trade, investment and tourism.Nepal's own geo-politics will be changed significantly and cooperation among three South Asian countries and China will be accelerated for mutual economic gain. How proximate is that idea from fructifying?

Former Minister of Physical Infrastructure and Transport Raghubir Mahaseth has said, "The government expects to get the detailed project report of the North-South railway project, which would link Kathmandu with China and India, within a year." He expected to receive the Kathmandu-Raxaul railway report from India within six months and that of Kathmandu-Kerung railway from China within nine months (The Himalayan Times, 2018). China plans to extend the rail link to Pokhara and Lumbini in the next phase. With India linking Raxaul with Kathmandu, the door becomes wide open for trilateral cooperation. Indian goods going to Kerung via Kathmandu and Chinese goods up to Raxaul Kathmandu will truly emerge as a "transit economy."

Moreover, this will open the possibility for Bangladesh to join in. Bangladesh will need to travel just 27 kilometers of Indian territory to reach Nepal through the shortest route. Bangladesh has allowed its territory to be used for Nepal's trade with other countries. At the 
moment, the only usable transit route between the two countries is through Fulbari in India's Siliguri. The transit agreement was done between Nepal and Bangladesh in 1976. However, even after 41 years, it is still not in effective use (Sangroula, 2017). The BanglabandhaKakarvitta Corridor is almost $61 \mathrm{~km}$ long, but there is still no agreement requiring India to permit the two countries to use its narrow strip of land for transit (The Financial Express. 2014). Nepal and Bangladesh must able to sort out the issue with India diplomatically to implement the transit deal. The prospective trilateral cooperation among China, Nepal and India will thus make it a quadrilateral one.

\section{Critical Issues}

Connectivity with advanced infrastructure is required for regional cooperation and integration. But even after 34 years after SAARC's establishment, South Asian countries are lagging in connectivity and cooperation. Some of the most critical issues behind it are dealt with here.

One of the major issues is Indo-Pakistan dispute that has been lingering since the independence of those countries. They have fought four wars -in 1947, 1965, 1971, and 1999 over disputed territories. Even when major wars are not taking place, both the countries are in a perpetual state of confrontation. Each time there is an escalation of the dispute, SAARC cooperation gets affected. The $19^{\text {th }}$ SAARC summit to be held in Pakistan could not be, due to tensions arising from Uri attack in 2016. Attacks on Indian paramilitary forces in Kashmir in February 2019 by Pakistan based terrorist groups leading to the death of about forty military personnel did not help with regards to SAARC cooperation on connectivity.

A similar conflict impacting regional connectivity is the CPEC project. The corridor which passes through disputed areas Gilgit-Baltistan brings in India, China and Pakistan to the fray. India wants a review of the CPEC route, but China and Pakistan seem reluctant. This has held India from officially joining BRI, a major connectivity initiative they will surely impact South Asian connectivity, eventually.

China's BRI move towards South Asia seems to be another issue for India. China claims that BRI was initiated for an economically win-win situation, whereas India perceives it as strategic move by China to encircle India's sphere of influence of in the region. This contradictory understanding of the two rising powers is also an issue for regional connectivity, particularly so for Nepal which is sandwiched between them.

In the larger strategic chessboard, the conflict of global powers threatens to spill over in the region. The existing Sino-Pakistani strategic partnership is likely to come in conflict with the budding Indo-US strategic partnership resulting in new issues with the potential of weakening South Asian connectivity. Delhi and Washington signed a deal in 2008 for nuclear cooperation (Council on Foreign Relations website). China and Pakistan have seen the deal as aimed against Beijing and Islamabad. Additionally, China is said to be opposing a proposal of India in the United Nations for reforming UNSC membership to get itself on board. These global issues have been reflected in regional cooperation and connectivity affairs.

Political instability is also an issue in the region. For example, Nepal was affected by political turmoil for a long time. Due to frequent change in government, Nepal could not initiate better connectivity projects with South Asian countries.

Uneven economic growth rates, size of their economy, wealth gaps, poor welfare distribution and poverty in most 
South Asian countries also impact connectivity. These hinder the capacity of each country to contribute uniformly on connectivity projects. Other economic issues are: unemployment rates, different rules and regulations governing the economy and varied institutional set ups. Inequalities in technological innovation and technology transfer too must be addressed by supporting the technologically deprived in the region.

Trade within the region has also seen unevenly distributed benefits to the countries. For example, Nepal runs trade deficit with other South Asian countries. According to Trade and Export Promotion Center (TEPC), the data of trade of Nepal with South Asian countries during the last 10 years is as below:

\begin{tabular}{|c|c|c|c|c|c|c|c|c|c|c|c|}
\hline \multicolumn{12}{|c|}{$\begin{array}{l}\text { Nepal's Trade with SAARC Member States } \\
\text { (Value in '000 NRs.) }\end{array}$} \\
\hline Countries & $\begin{array}{l}\text { Export/ } \\
\text { Import }\end{array}$ & $\begin{array}{l}\text { F.Y.2008 } \\
\text { /09 }\end{array}$ & $\begin{array}{l}\text { F.Y.2009/1 } \\
0\end{array}$ & $\begin{array}{l}\text { F.Y. } \\
2010 / \\
11\end{array}$ & $\begin{array}{l}\text { F.Y.2011/ } \\
12\end{array}$ & $\begin{array}{l}\text { F.Y.2012/ } \\
13\end{array}$ & $\begin{array}{l}\text { F.Y.2013/ } \\
14\end{array}$ & $\begin{array}{l}\text { F.Y.2014/ } \\
15\end{array}$ & $\begin{array}{l}\text { F.Y.2015/ } \\
16\end{array}$ & $\begin{array}{l}\text { F.Y.2016/ } \\
17\end{array}$ & $\begin{array}{l}\text { F.Y.2017/ } \\
18\end{array}$ \\
\hline \multirow[t]{2}{*}{ Afghanistan } & Exports & 2,346 & 973 & 4,394 & 97,884 & 606,660 & $1,520,370$ & $1,601,855$ & 206,058 & 103 & 20,893 \\
\hline & Imports & 6,225 & 7,384 & 255 & 300 & 9,004 & 787 & 7,255 & 88,402 & 1,235 & 1,950 \\
\hline \multirow[t]{2}{*}{ Bangladesh } & Exports & $\begin{array}{l}4,710,40 \\
2\end{array}$ & $3,373,718$ & $\begin{array}{l}3,471 \\
, 938\end{array}$ & $2,578,080$ & $2,730,217$ & $2,140,486$ & $1,084,414$ & $1,208,104$ & $1,047,913$ & $1,083,024$ \\
\hline & Imports & 418,014 & 764,830 & $\begin{array}{l}1,104 \\
, 150\end{array}$ & $1,502,817$ & $2,174,027$ & $1,728,648$ & $2,731,096$ & $4,000,482$ & $4,226,702$ & $4,791,034$ \\
\hline \multirow[t]{2}{*}{ Bhutan } & Exports & 194,826 & $1,554,824$ & $\begin{array}{l}425,4 \\
84\end{array}$ & 543,836 & 333,879 & 99,532 & 121,368 & 152,713 & 77,406 & 75,872 \\
\hline & Imports & 352,367 & 133,152 & $\begin{array}{l}112,2 \\
34\end{array}$ & 249,412 & 273,078 & 353,201 & 405,774 & 547,893 & 531,414 & $1,637,784$ \\
\hline \multirow[t]{2}{*}{ India } & Exports & $\begin{array}{l}43,574,4 \\
82\end{array}$ & $39,902,811$ & $\begin{array}{l}42,86 \\
8,108\end{array}$ & $\begin{array}{l}50,933,22 \\
2\end{array}$ & $\begin{array}{l}51,788,46 \\
0\end{array}$ & $\begin{array}{l}59,458,37 \\
5\end{array}$ & $\begin{array}{l}55,859,25 \\
3\end{array}$ & $\begin{array}{l}39,695,13 \\
4\end{array}$ & $\begin{array}{l}41,500,84 \\
4\end{array}$ & $\begin{array}{l}46,661,56 \\
4\end{array}$ \\
\hline & Imports & $\begin{array}{l}165,119 \\
002\end{array}$ & $\begin{array}{l}214,261,10 \\
9\end{array}$ & $\begin{array}{l}259,1 \\
62,27 \\
7\end{array}$ & $\begin{array}{l}321,346,4 \\
19\end{array}$ & $\begin{array}{l}397,957,9 \\
20\end{array}$ & $\begin{array}{l}482,345,3 \\
00\end{array}$ & $\begin{array}{l}500,044,4 \\
84\end{array}$ & $\begin{array}{l}487,597,3 \\
07\end{array}$ & $\begin{array}{l}646,019,0 \\
17\end{array}$ & $\begin{array}{l}812,551,4 \\
61\end{array}$ \\
\hline \multirow[t]{2}{*}{ Maldives } & Exports & 4,007 & 289 & 461 & 1,688 & 21,881 & 5,042 & 8,600 & 50 & 57 & 559 \\
\hline & Imports & 71 & - & 927 & 510 & 32 & 12 & 13,652 & 33 & 9 & 172 \\
\hline \multirow[t]{2}{*}{ Pakistan } & Exports & 86,003 & 78,971 & $\begin{array}{l}142,3 \\
38\end{array}$ & 225,907 & 139,886 & 86,976 & 28,777 & 47,719 & 155,478 & 37,316 \\
\hline & Imports & 248,893 & 281,240 & $\begin{array}{l}293,7 \\
47\end{array}$ & 266,286 & 344,581 & 350,200 & 415,858 & 271,734 & 435,794 & $6,312,303$ \\
\hline \multirow[t]{2}{*}{ Sri Lanka } & Exports & 161,544 & 100,263 & 7,568 & 22,162 & 5,438 & 2,525 & 38,845 & 9,361 & 2,550 & 8,955 \\
\hline & Imports & 58,224 & 54,773 & 151,7 & & & & & & & \\
\hline
\end{tabular}




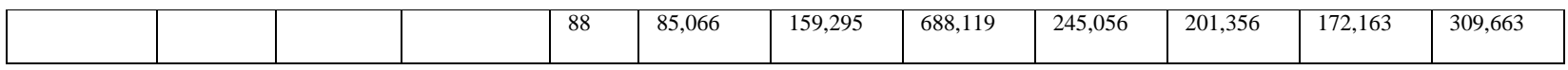

Source: Trade \& Export Promotion Center, Government of Nepal

The calculation of Nepal's average trade with all South Asian countries during past 10 years is given below:

\begin{tabular}{|l|l|}
\hline \multicolumn{2}{|l|}{ Nepal's average trade with SAARC countries during past 10 years } \\
\hline Country & Amount In Million (NRs.) \\
\hline Afghanistan & 393.2327 \\
\hline Bangaldesh & -1.351 \\
\hline Bhutan & -101.657 \\
\hline India & -381416.204 \\
\hline Maldives & 2.721644 \\
\hline Pakistan & -819.126437 \\
\hline Srilanka & -176.629 \\
\hline
\end{tabular}

Source: Source: Trade \& Export Promotion Center, Government of Nepal

Data shows that Nepal's trade is in deficit with five of the other South Asian countries during the past 10 years. Only with Afghanistan and Maldives, Nepal has had an average surplus and even here the trade volume is small. This is the biggest issue of Nepal regarding Nepal's connectivity with other South Asian countries. Better connectivity would help increase trade flow, but if the deficit too widens as a result it would result in an unsustainable trading regime. This means that the trade regime problems too need to be addressed while pursuing connectivity.

There is also concern over unnecessary debates that pit SAARC against BIMSTEC. BIMSTEC is not a replacement for SAARC, but complementary. Only, close cooperation between SAARC and BIMSTEC will enhance South Asian regional connectivity. Basically, SAARC is the main vehicle for regional cooperation including connectivity. Its broader objectives should be driving other sub-regional forums like BIN, CNIB, and BCIM etc.

Likewise, lackluster enthusiasm to implement SAARC decisions, psychological fear of Indian dominance in smaller countries and fear of ganging up by other countries against India all impact cooperation, and, hence, connectivity. The trust deficit in the region also must be addressed. Similarly, SAARC's inter-governmental decision making structure has not kept up with global trends and South Asian demands. Decision making process in SAARC takes time, which slows down the speed of the work regarding connectivity.

Soft power cooperation is another important factor regarding connectivity. Every South Asian country is unique in the kind of soft power they possess- the cultures, languages, festivals, belief systems, history etc. may be similar in many aspects, but there are differences that must also be respected. For better cooperation in the region, these 
various values require intra-regional institution building with the objective of enhancing the connectivity process. Such institutions can conduct events of knowledge and information sharing through conferences, publication etc. Such soft power cooperation requires mobilization of all the tracks of diplomacy for bilateral and multilateral deals.

\section{Conclusion}

If the policy of South Asian countries to be connected with other countries in the region via road, rail link, water way and air link is to be effective, then Connecting Diplomacy should be pursued, especially in the South Asian region where connectivity projects must move faster to life the whole region towards prosperity. Such focused diplomacy will deal with all the issues of regional connectivity. A multi-generational and multilateral think tank could do the vigorous research and publication regarding the critical issues of connectivity. Universities from South Asian countries should be connected through MoUs for unique cooperation to do joint research and publication at the regional level. Same goes for university student networks.

While looking for ways to resolve the critical issues pointed out earlier, the regional countries should do well by adopting connectivity ideas without impinging on each other's sovereignty, but instead promoting their mutual benefits and interests so that they can work towards a common destiny for the region unhindered and unencumbered.

Hari P. Chand, (agnipunja@yahoo.com) a first-cohort MA graduate from DIRD and pursuing PhD in IRD at the Department of International Relations and Diplomacy, Tribhuvan University

\section{References}

Adhikari, R., Chaulagain, Y. P., Dhakal, T. P. and Subedi, S. B. 2013. From a Buffer towards a Bridge (Nepal's New Foreign Policy Agenda). Kathmandu. Institute of Foreign Affairs.

Bose, P. R. 2018. Bhutan says exit from BBIN motor vehicles pact is temporary. The Hindu,

Jan 11. https://www.thehindubusinessline.com/economy/logistics/bhutan-says-exit-frombbin-motor-vehicles-pact-is-temporary/article9685062.ece

Bose, P. R. 2018. India starts construction of 1600-cr Mizoram-Myanmar Kaladan road. The Hindu, April 17. https://www.thehindubusinessline.com/news/india-starts-construction-of1600-cr-mizoram-myanmar-kaladan-road/article23577107.ece

Byanjankar, R. 2018. Yawning trade deficit: It's hurting our economy. The Himalayan Times,

July 18. https://thehimalayantimes.com/opinion/yawning-trade-deficit-its-hurting-oureconomyl

Chand, H. P. 2018. Nepal PM's China visit puts ties on a new road. Global Times, July 01. Retrieved from http://www.globaltimes.cn/content/1108988.shtml

Chaudhury, D. R. 2018. Bangladesh: A regional connectivity hub linking South Asia with Southeast Asia. Economic Times, November 
https://economictimes.indiatimes.com/news/politics-and-nation/bangladesh-a-regionalconnectivity-hub-linking-south-asia-with-southeast-asia/articleshow/66554793.cms

Ghosh, Peu. 2013. International relations. Delhi: PHI Learning Private Limited.

Gokmen, S. R. 2010. Geopolitics and the Study of International Relations. (Unpublished Doctoral dissertation). Middle East Technical University.

Karim, M. H. and F. Islam. 2018 June. Bangladesh-China-India-Myanmar (BCIM) Economic Corridor:

Challenges and Prospects. The Korean Journal of Defense Analysis. 30(2): 283.

KC, Khadga and Chand, Hari Prakash. 2018 January. Sino-Indian relations: Implications to Nepal. Journal of Asian Politics and Society, 2(1), 50.

Khanna, Parag. 2017. What if connectivity were the new geo-strategic game changer?. Shaping the Future of Geopolitics, (n.v.), 21.

Ministry of External Affairs. 2018. India-Nepal Statement on New Connectivity through Inland Waterways. Ministry of Foreign Affairs, April 07. https://mea.gov.in/bilateraldocuments.htm?dtl/29796/IndiaNepal_Statement_on_New_Connectivity_through_Inland Waterways

Ministry of External Affairs. 2018. Preliminary Engineering-cum-Traffic Survey of Raxaul (India) -Kathmandu (Nepal) rail line. Ministry of External Affairs, August 31. https://www.mea.gov.in/press-

releases.htm?dt1/30337/Preliminary+EngineeringcumTraffic+Survey+of+Raxaul+India+K athmandu+Nepal+rail+line

Nayak, Nihar R. 2014. Strategic Himalays (Republican Nepal and External Power). New Delhi: Institute for Defense Studies and Analyses.

Neupane, S. R. 2018. Nepali team visits India to study inland waterways. The Kathmandu Post, September 17. http://kathmandupost.ekantipur.com/news/2018-09-17/nepali-team-visitsindia-to-study-inland-waterways.html

Pillalamarri, Akhilesh. 2016. A Brief History of Balochistan. The Diplomat, February 12. https://thediplomat.com/2016/02/a-brief-history-of-balochistan/

Pradhan, P. R. 2018. Nepal: From Landlocked to Land Linked. Peoples Review, March 28. http://peoplesreview.com.np/nepal-from-land-locked-to-land-linked/

Pradhan, T. R. 2018. 2018 saw cracks within Nepal's ruling party. Here's why 2019 might be the year of revolution within the Communist Party. The Kathmandu Post, December 30. http://kathmandupost.ekantipur.com/news/2018-12-30/2018-saw-cracks-within-nepalsruling-party-heres-why-2019-might-be-the-year-of-revolution-within-the-communist- 
party.html

Rafiq, A. 2016. India's Modi is Playing the Wrong Game against China and Pakistan. National Interest, $\quad$ August 21 www.nationalinterest.org: http://nationalinterest.org/feature/indias-modi-playing-the-wrong-game-against-chinapakistan-17411

SAARC. 1985. Charter of the South Asian Association for Regional Cooperation. http://saarc-sec.org/saarc-charter

Sangroula, Y. 2017, April. China South Asia connectivity: Reflections on benefits of OBOR in Nepal from International Law perspective. Kathmandu School of Law Review, 5, 9-35.

Sangroula, Yubaraj. 2017, April. China South Asia Connectivity: Reflections on Benefits of OBOR in Nepal from International Law Perspective. Kathmandu School of Law Review, 5: 9

Saran, Shyam. 2018. Why regional connectivity in South Asia should be a strategic priority for India. Hindustan Times, April 12. https://www.hindustantimes.com/analysis/whyregional-connectivity-in-south-asia-should-be-a-strategic-priority-for-india/storyF54OnZRLWM22kbr2LmS7BM.html

Shahid, U. 2016. Balochistan: The Troubled Heart of the CPEC. The Diplomat, August 23. www.thediplomat.com: http://thediplomat.com/2016/08/balochistan-the-troubled-heart-ofthe-cpec

Shrestha, B. N. 2015. Nepal-China Seven Border Crossing Points. Nagarik Daily, November 18:7.

Tao, L. 2017. Himalaya regional cooperation can promote B \& R, boost China's bilateral ties. Global Times, September 11. http://www.globaltimes.cn/content/1065923.shtml

The Financial Express. 2014. Thrust on Banglabandha-Phulbari-Kakarvita Corridor to bolster regional trade. The Financial Express, October 21. http://print.thefinancialexpressbd.com/2014/10/21/62202

The Himalayan Times. 2018. DPR of North-South railway project within a year: Minister Mahaseth. $\quad$ The Himalayan Times, August 17. https://thehimalayantimes.com/kathmandu/dpr-of-north-south-railway-project-within-ayear-minister-mahaseth/

Uberoi, P. 2013. "The BCIM Forum: Retrospect and Prospect," ICS Working Paper, no. 1, New Delhi Institute of Chinese Studies, November 1, 2011, www.icsin.org/publications/ the-bcim-forum-retrospect-and-prospect (accessed August 20, 2017).http://hr.parliament.gov.np/np/members 
Hari Prakash Chand / Critical Issues Related to Connectivity ... Vol. 3, 68-83, 2020

http://mea.gov.in/bilateral-

documents.htm?dtl/3886/16th+SAARC+Summit+Declaration+29+April+2010

http://www.worldbank.org/en/about/what-we-do

https://myrepublica.nagariknetwork.com/news/nepal-set-to-get-access-to-seven-china-ports/

https://www.adb.org/about/infrastructure

https://www.adb.org/publications/connectivity-driven-development-strategy-nepal-landlocked-

land-linked-state

https://www.aiib.org/en/about-aiib/index.html

https://www.cfr.org/backgrounder/us-india-nuclear-deal

https://www.iru.org/system/files/BBIN\%20media\%20fact\%20sheet_0.pdf

https://www.onlinekhabar.com/2019/02/742227 